The purpose of our article was to show that, if phlebography is to be performed, it is better to do it immediately than to admit the patient and perform the investigation during more convenient working hours. The authors' letter appears to have little or no relevance to our original article.

M J Charig E W L FLETCHER

Department of Radiology, John Radcliffe Hospital, John Radcliffe Hospit

\section{Cardiac tamponade}

SIR,-Dr John Horgan discusses the clinical presentation of cardiac tamponade in terms of respiratory distress and shock and emphasises the importance of early diagnosis (5 September, p 563). A further symptom may help in preventing delay in diagnosis: dysphagia was found in three consecutive cases seen recently at this hospital.

In each case the origin of the tamponade was malignant disease; cytological examination of pericardial fluid and sputum disclosed adenocarcinomatous cells. All three patients (aged 54, 65, 65) were smokers. While each patient complained predominantly of progressive breathlessness, which became rapidly worse around the time of admission, their dysphagia was scarcely less distressing. After pericardiocentesis (the volume of effusion drained ranged from 1.5 to 2.5 litres) not only was breathlessness improved but dysphagia was relieved. This suggests a direct pressure effect of the enlarged pericardial sac on the oesophagus, by analogy with mitral stenosis, where left atrial enlargement may also cause dysphagia. ${ }^{1}$

In a review of pericardial constriction Hirschmann gave dysphagia as a symptom, ${ }^{2}$ and Thurber et $a l^{\beta}$ describe 10 of 55 patients with malignant pericardial disease complaining of dysphagia, but it is not mentioned in the Oxford Textbook of Medicine $^{4}$ or Hurst's The Heart..$^{5}$ In any patient with respiratory distress and dysphagia the possibility of cardiac tamponade should be considered.

Selly Oak Hospital

Birmingham B29

1 Dines DE, Anderson MW. Giant left atrium as a cause of dysphagia. Ann Intern Med 1966;65:759-61.

2 Hirschmann JV. Pericardial constriction. Am Heart J 1978;96: $110-22$.

3 Thurber DL, Edwards JE, Archer RWP. Secondary malignant tumours of the pericardium. Circulation 1962;26:228.

4 Gibson DG. Pericardial disease. In: Weatherall DJ, Ledingham JGG, Warrell DA, eds. Oxford textbook of medicine. 2nd ed. Oxford: Oxford University Press, 1987.

5 Logue RB. Etiology, recognition and management of pericardial disease. In: Hurst JW, ed. The heart. Sth ed. New York: McGraw Hill, 1982.

\section{Dysphagia in acute stroke}

SIR,-Dr Caroline Gordon and colleagues dealt with dysphagia as a complication of acute stroke (15 August, $\mathrm{p}$ 411). Although we would intuitively agree with the points of this paper, we do not think that the main conclusions can be accepted on the evidence given.

There are major methodological problems. Admission criteria are not clearly stated. Patients were entered in the study up to two weeks after the occurrence of an acute stroke. In $44 \%$ of cases dysphagia had resolved within two weeks. Some of the "patients without dysphagia" therefore probably did have dysphagia which had resolved by the time of entry in the trial. The assessment of dehydration appears to have been based on fluid balance charts and measurements of packed cell volume and urea concentrations, but they admit that the data collected for both groups of patients are incomplete. Criteria for the definition of chest infection are not given. No statistically significant difference in the incidence of chest infection was found between those with and those without dysphagia. No statistical support is given for the apparent differences in packed cell volume and urea between the two groups.

This study gives clear evidence that dysphagia may complicate unilateral cerebral hemisphere stroke, that it is associated with more severe or multiple strokes, and that it is associated with an increased risk of death (although the assumption that unconscious patients had dysphagia may have confounded the results). The concluding paragraph states that "if dysphagia is identified early after a stroke happens dehydration and chest infections may be prevented with nasogastric tubes or intravenous fluids until swallowing recovers." On the same data it might be rephrased "no significant difference was found in the incidence of chest infection or dehydration between those with and those without dysphagia in the first two weeks of stroke. There are insufficient data to support a change in current medical practice. Further research is needed."

We also have recognised that many of the patients with stroke in our unit have swallowing problems in the early stages. We find it useful to involve a speech therapist in the management and assessment of such patients as soon as they are fully conscious. Swallowing therapy can help to reestablish and coordinate the swallow, even before oral feeding is possible or safe. In some cases a palatal training appliance improves swallowing coordination and drooling. This consists of a wire loop attached to a dental plate. It is well tolerated and easily fitted. ${ }^{1}$

\section{J A BARRETT \\ K J FULLERTON R WYATT \\ P A O'NeILL}

\section{Department of Geriatric Medicine,}

University Hospital of South Manchester,

Manchester M20 8LR.

1 Selley WG. Swallowing difficulties in stroke patients: a new treatment. Age Ageing 1985;14:361-5.

AUTHOR'S REPLY,-The admission criteria are stated clearly and covered 91 consecutive patients admitted to a district general hospital with a clinical diagnosis of acute stroke. We think it likely that these patients were typical of patients with stroke admitted to any district general hospital. Sixty one per cent of patients were seen within 48 hours and $90 \%$ within 96 hours of the onset of the stroke. Allowing for delays incurred at home, on ambulance journeys, and at weekends, it seems unlikely that the figures could be improved without more staff. We accept that some patients with dysphagia may have been missed. This could have occurred, for example, in patients who died before reaching hospital or those in whom dysphagia was a transient event which cleared rapidly before, or shortly after, admission to hospital. We also accept that more work needs to be done on the problem of dehydration and its consequences.

Criteria for the definition of chest infections are given in the methods section. We agree that the numbers are small and that the difference between the two groups does not reach statistical significance.

We agree that speech therapists can frequently help patients with dysphagia. We also have experiences of using palatal appliances in a different context. ${ }^{1}$ We do not think, however, that a palatal training device would be appropriate for a condition that usually resolves within 14 days.

Finally, we cannot agree with the penultimate paragraph of the letter. Dysphagia is a highly dangerous complication of an acute stroke. Swallowing should be tested in all cases, and if the patients cannot swallow some alternative method of giving fluids should be used. This recommendation does not appear in any of the standard textbooks. Certainly more research is needed.

R LANGTON HEWER

Frenchay Hospital,

Bristol BS16 1LE

1 Enderby PM, Langton-Hewer R. Communication and swallowing. In: Cochrane GM, ed. Management of motor neurone disease. London: Churchill Livingstone, 1987:34-5.

SIR,-Dr Caroline Gordon and colleagues have confirmed (15 August, p 411) that dysphagia is a common but generally transient problem after stroke affecting a single cerebral hemisphere and that difficulty in swallowing is associated with an increased early mortality. This relation is confounded, however, by the association between dysphagia and overall severity of stroke, which they also showed.

The $\beta$ blocker stroke (BEST) study carried out in Nottingham is now complete, ${ }^{12}$ and data are available from 357 conscious stroke victims seen within $\mathbf{4 8}$ hours of the onset of strokes that, by clinical criteria, affected only one cerebral hemisphere. From the table it can be seen that the $29 \%$ of patients with impairment of swallowing on day 1 were more likely to be drowsy (and to have other adverse signs) but that they had a substantially increased early mortality, regardless of the initial state of alertness. On the other hand, the pattern of clinically determined causes of death was similar in those with and without swallowing problems, apart from an excess of primary brain deaths, which might be expected in a group with more severe strokes. Moreover, the mean changes in packed cell volume and blood urea concentrations over the first week in surviving patients with dysphagia who were not given intravenous or nasogastric fluid did not differ significantly from those in patients who did not have dysphagia.

Thus any tendency to dehydration or chest infection in conscious stroke victims with transien swallowing difficulty may not be severe enough to add substantially to the early mortality, but more research is needed to determine whether failure to

Outcome in 357 stroke victims with or without impairment of swallowing

\begin{tabular}{|c|c|c|c|c|c|c|c|c|c|c|}
\hline \multirow{3}{*}{$\begin{array}{l}\text { Swallowing } \\
\text { on day } 1\end{array}$} & \multirow{2}{*}{\multicolumn{3}{|c|}{$\begin{array}{l}\text { No of patients } \\
\text { (\% mortality in first month) }\end{array}$}} & \multirow{3}{*}{$\begin{array}{l}\text { Total No } \\
\text { of deaths } \\
\text { in } 6 \text { months }\end{array}$} & \multicolumn{6}{|c|}{$\%$ Of deaths attributed to each cause } \\
\hline & & & & & \multirow{2}{*}{$\underset{\text { brain death }}{\text { Primary }}$} & \multirow[b]{2}{*}{ Pneumonia } & \multirow{2}{*}{$\begin{array}{l}\text { Pulmonary } \\
\text { embolism }\end{array}$} & \multirow[b]{2}{*}{ Cardiac* } & \multirow{2}{*}{$\begin{array}{c}\text { Renal } \\
\text { failure }\end{array}$} & \multirow{2}{*}{ Other } \\
\hline & All & Alert & Drowsy & & & & & & & \\
\hline $\begin{array}{l}\text { Normal } \\
\text { Impaired }\end{array}$ & $\begin{array}{l}250(10) \\
107(48)\end{array}$ & $\begin{array}{c}210(7) \\
36(33)\end{array}$ & $\begin{array}{l}40(23) \\
71(55)\end{array}$ & $\begin{array}{l}40 \\
61\end{array}$ & $\begin{array}{l}10 \\
20\end{array}$ & $\begin{array}{l}43 \\
44\end{array}$ & $\begin{array}{l}25 \\
25\end{array}$ & $\begin{array}{l}15 \\
10\end{array}$ & $\begin{array}{l}3 \\
2\end{array}$ & $\begin{array}{l}5 \\
0\end{array}$ \\
\hline Total & $357(21)$ & $246(11)$ & $111(43)$ & 101 & 16 & 44 & 25 & 12 & 2 & 2 \\
\hline
\end{tabular}

^Heart failure, myocardial infarction, arrhythmia. 